\title{
DO LOGOS AO MITO: A UNIVERSALIZAÇÃO POÉTICA DO REGIONALISMO EM TRÊS “ESTÓRIAS” DE JOÃO GUIMARÃES ROSA
}

\section{FROM LOGOS TO MYTHS: THE UNIVERSALIZATION OF REGIONALISM IN THREE STORIES OF JOÃO GUIMARÃES ROSA}

Manoel Francisco Guaranha ${ }^{1}$

RESUMO: Este trabalho analisa três narrativas de João Guimarães Rosa pertencentes à obra Primeiras Estórias: "O Cavalo que bebia cerveja", "Sorôco, sua mãe e sua filha" e "A Terceira margem do rio". Os textos são analisados sob a perspectiva do conceito de literariedade e da visão do fenômeno literário centrado numa compreensão do estilo como um modo de unir a palavra ao pensamento; o estudo destaca Guimarães Rosa, como um autor que procura, por meio do uso especial da linguagem, a universalização do regionalismo.

PALAVRAS-CHAVE: Literatura Brasileira; Guimarães Rosa; Estilo; Literariedade.

ABSTRACT: This paper analyzes three stories of João Guimarães Rosa's book Primeiras estórias: "O Cavalo que bebia cerveja", "Sorôco, sua mãe e sua filha" and "A Terceira margem do rio". These texts are analyzed from the perspective of the concept of literariness and of the literary phenomenon focused in an understanding of the style as a way to unite the word to thought. The study highlights Guimarães Rosa as an author who seeks the universalization of regionalism through the special use of language.

KEYWORDS: Brazilian Literature; Guimarães Rosa; Style; literariness.

\section{Considerações iniciais}

Este trabalho está inserido na linha de pesquisa "Estudos estilísticos: discurso, gramática e estilo" do Programa de Mestrado em Linguística da Universidade Cruzeiro do Sul, UNICSUL, e analisa três narrativas contidas na obra Primeiras Estórias, de João Guimarães Rosa: "O Cavalo que bebia cerveja", "Sorôco, sua mãe e sua filha" e "A Terceira margem do rio" com o objetivo de compreender como esses textos reconstroem literariamente os temas da busca de identidade, da dicotomia entre a razão e a loucura e da busca da transcendência por meio de uma linguagem mitopoética que assume a dupla

\footnotetext{
${ }^{1}$ Professor da Universidade Cruzeiro do Sul - UNICSUL, São Paulo, São Paulo, Brasil e da Faculdade de Tecnologia FATEC, São Paulo, São Paulo, Brasil; m-guaranha@uol.com.br.
} 
função de redimensionar o caráter meramente documental do regionalismo tradicional e pitoresco, universalizando-o; e potencializar o poder expressivo da palavra, retirando-a da primazia do logos e devolvendo-lhe ao plano do mito, por meio de procedimentos estilísticos que consistem em desconvencionalizar o uso da língua por meio do estranhamento e do reestabelecimento de relações mais diretas entre a palavra e a natureza das coisas.

Segundo o estruturalismo russo, "a finalidade da arte é dar uma sensação do objeto como visão e não como reconhecimento; o processo da arte é o processo de singularização dos objetos e o processo que consiste em obscurecer a forma, em aumentar a dificuldade e a duração da percepção" (CHKLOVSKI, 1999, 81). Tal conceito surgiu da tentativa desses estudiosos de estabelecerem o conceito de literariedade, ou seja, compreender o que faz um texto ser ou não literário. Nasceu, assim, a ideia de que o discurso cotidiano é automatizado, o que leva as palavras, muitas vezes, a serem pronunciadas apenas pela metade: "Os objetos várias vezes percepcionados começam a ser percepcionados por um reconhecimento: o objeto encontra-se diante de nós, nós sabe-mo-lo, mas já não o vemos" (CHKLOVSKI, 1999, 82). Dessa forma, os objetos evocados pelo discurso não são vistos, mas reconhecidos apenas pelos seus primeiros traços, vemos apenas a sua superfície, a percepção diminui, "a vida desaparece, transformando-se num nada. A automatização traga os objetos, os fatos, os móveis, a mulher e o medo da guerra" (CHKLOVSKI, 1999, 81). Assim, a arte existe para devolver ao indivíduo a sensação da vida, "para sentir os objetos, para sentir que pedra é pedra" (CHKLOVSKI, 1999, 81).

Embora hoje em dia muitos conceitos do Estruturalismo tenham sido relativizados (EAGLETON, 2003), devemos reconhecer que as reflexões dessa corrente teórica abriram caminho para uma nova abordagem da obra literária: uma abordagem que considera, preferencialmente, a matéria-prima do fenômeno, a palavra, bem como seu arranjo, ou seja, fatores intrínsecos à literatura, e não apenas dados extrínsecos que, se por um lado colaboram na interpretação da obra, muitas vezes eram postos em primeiro plano, submetendo a literatura a fatores contextuais, históricos, biográficos, sociológicos, psicológicos entre outros, vale dizer transformando o texto literário em pretexto para estudos de toda ordem. 
É sob essa perspectiva que podemos destacar certa hierarquia das funções da literatura na sociedade como descreve Candido (1995) cujo ponto máximo encontra-se na visão da obra enquanto objeto autônomo linguisticamente construído:

A função da literatura está ligada à complexidade da sua natureza, que explica inclusive o papel contraditório mas humanizador (talvez humanizador porque contraditório). Analisando-a, podemos distinguir pelo menos três faces: (1) ela é uma construção de objetos autônomos como estrutura e significado; (2) ela é uma forma de expressão, isto é, manifesta e moções e a visão do mundo dos indivíduos e dos grupos; (3) ela é uma forma de conhecimento, inclusive Como in corporação difusa e inconsciente.

Em geral pensamos que a literatura atua sobre nós devido ao terceiro aspecto isto é, porque transmite uma espécie de conhecimento, que resulta em aprendizado, como se ela fosse um tipo de instrução.

Mas não é assim. O efeito das produções literárias é devido à atuação simultânea dos três aspectos e, embora costumemos pensar menos no primeiro, que corresponde à maneira pela qual a mensagem é construída; mas essa maneira é o aspecto, senão mais importante, com certeza crucial, porque é o que decide se uma comunicação é literária ou não[...]

Toda obra literária é antes de mais nada uma espécie de objeto, de objeto construído; e é grande o poder humanizador desta construção, enquanto construção. (CANDIDO, 1995, p. 176-177).

Em João Guimarães Rosa essa consciência da linguagem literária como fator de desautomatização da realidade, como elemento que revela a natureza íntima das coisas e as inquietações originais do Homem, não apenas do sertanejo, seu fator humanizador, parece ter sido levada às últimas consequências.

Colabora com isso a especial escolha de temas do corpus roseano composto de uma constelação de "estórias" que emergem de um universo rapsódico marcado pelo sabor da oralidade e costurado por um amarrador de mitos, que se corporifica na figura do narrador. Esse processo vai ao encontro de uma concepção abrangente de literatura em que se fundem popular e erudito, oralidade e escrita, sonho e realidade, como a apresentada por Antonio Candido:

Chamarei de literatura, da maneira mais ampla possível, todas as criações de toque poético, ficcional ou dramático em todos os níveis de uma sociedade, em todos os tipos de cultura, desde o que chamamos folclore, lenda, chiste, até as formas mais complexas e difíceis da produção escrita das grandes civilizações. Vista deste modo a literatura aparece claramente como 
Revista InterteXto / ISSN: 1981-0601

v. 6 , n. 2 (2013)

manifestação universal de todos os homens em todos os tempos. Não há povo nem há homem que possa viver sem ela, isto é, sem a possibilidade de entrar em contato com alguma espécie de fabulação. Assim como todos sonham todas as noites, ninguém é capaz de passar as vinte e quatro horas do dia sem alguns momentos de entrega ao universo fabulado. $O$ sonho assegura durante o sono a presença indispensável deste universo, independentemente a nossa vontade. E durante a vigília a criação ficcional ou poética, que é a mola da literatura em todos os seus níveis e modalidades, está presente em cada um de nós, analfabeto ou erudito, como anedota, causo, história em quadrinhos, noticiário policial, canção popular, moda de viola, samba carnavalesco. Ela se manifesta desde o devaneio amoroso ou econômico no ônibus até a atenção fixada na novela de televisão ou na leitura seguida de um romance (CANDIDO, 1995, p. 174-175).

Guimarães Rosa também, como observa Candido(2000),

...quis e conseguiu elaborar um universo autônomo, composto de realidades expressionais e humanas que se articulam em relações originais e harmoniosas, superando por milagre o poderoso lastro de realidade tenazmente observada, que é a sua plataforma. (...) A experiência documentária de Guimarães Rosa, a observação da vida sertaneja, a paixão pela coisa e pelo nome da coisa, a capacidade de entrar na psicologia do rústico, - tudo se transformou em significado universal graças à invenção, que subtrai o livro à matriz regional para fazê-lo exprimir os grandes lugares comuns, sem os quais a arte não sobrevive: dor, júbilo, ódio, amor, morte - para cuja órbita nos arrasta a cada instante, mostrando que o pitoresco é acessório e que na verdade o Sertão é o Mundo (CANDIDO, 2000, 122).

Embora Candido esteja se referindo à obra Grande Sertão: Veredas, a qualidade linguística apontada estende-se a toda a produção Roseana. Como se percebe, o crítico põe em questão a plataforma documental em que se apóia o autor e a transcendência desse universo, graças à invenção linguística: "a paixão pela coisa e pelo nome da coisa". É nesse aspecto que encontramos a visada Roseana que consegue, pela evidência que dá à palavra, singularizá-la, assim como aquilo que ela representa, aumentado a percepção não só das realidades a que as expressões fazem referência, mas aumentando também a percepção dessa mesma realidade.

Se o Regionalismo de 1930 pretendera dialogar com a cultura dominante de forma lúcida e crítica, como afirma Alfredo Bosi, no Regionalismo de Guimarães o sertão parece que se transforma no próprio homem, tende a "fechar-se às contradições com a sociedade englobante" (BOSI,1978, p.12), efeito que é obtido por meio do mito: 
Revista InterteXto / ISSN: 1981-0601

v. 6 , n. 2 (2013)

A forma interna dessa comunhão de sujeito e mundo é um estilo que reativa as potências sonoras e simbólicas da palavra. Não se trata de uma simples volta ao vocabulário arcaico ou à frase coloquial sertaneja(...); trata-se de estender os princípios criadores da língua mitopoética a todo o tecido narrativo. A palavra nova não é puro neologismo, pois retoma um processo de formação que vem de longe, de muito longe; assim, de um salto, o tempo é abolido, e o signo arcaico e moderno - simula o eterno presente. A frase, por sua vez, estranhamente livre, truncada e revolta, parece às vezes driblar o nexo fundamental que une predicado a sujeito. E a hora de fazer cintilar o nome, imagem da substância, misterioso, além ou aquém das determinações verbais. (BOSI, 1978, 13)

Desse modo, se Guimarães Rosa busca a linguagem literária no falar sertanejo, também a tempera com o conhecimento que possui do mecanismo de várias línguas: o italiano, o francês, o alemão, o latim entre outras. Assim, para além de um uso especial e sistemático da língua, que acabaria se transformando em uma nova convenção, o autor surpreende a essência poética da linguagem em sua fonte arcaica, que reside no mito, compreendido aqui como narrativa primordial.

É sob esta perspectiva que podemos destacar as especificidades do estilo roseando, sua marca atemporal que transcende rótulos de escola ou de tendências. Sendo assim, é necessário um estudo que se fundamente nos dois princípios propostos por Bally(s/d) em seu Traité de stylistique française:

A. Le premier est négatif: lutter autant que possible contre les méthodes traditionnelles partout où celles-ci réduisent l'étude des langues à un travail à la fois automatiqtie, analytique et historique: automatique par tendance au moindre effort, analytique par contre-coup, historique par routine et, pour ainsi dire, sans le savoir.

$B$. Le second principe est positif: il tend à montrer que l'étude d'une langue n'est pas seulement l'observation des rapports existant entre des symboles linguistiques, mais aussi des relations qui unissent la parole à la pensée, que c'est une étude en partie psychologique, en tant qu'elle est basée sur l'observation de ce qui se passe dans l'esprit d'un sujet parlant aumoment où il exprime ce qu'il pense; une élude plus linguistique que psychologique cependant, en ce qu'elle est tournée vers la face expressive de la pensée et non vers la face pensée des faits exprimés. (BALLY, s/d, p. 2).

O primeiro princípio (A) vai justamente ao encontro da essência do conceito de literatura proposto pelos estruturalistas: uma forma de expressão que concorre para a 
desautomatização da linguagem deve, certamente, ser estudada sob uma perspectiva que nega os métodos tradicionais que tendem a automatizar seus processos.

O segundo princípio (B) alinha-se tanto à perspectiva de Candido sobre a literatura como um objeto linguístico, ou seja, a face expressiva do pensamento e não a face psíquica dos fatos de expressão, como também acerca do regionalismo peculiar de Guimarães Rosa, que transcende o aspecto documental, já que o estudo de uma língua, e do texto literário, é concebido não é somente por meio da observação das relações existentes entre os signos linguísticos, e entre os signos linguísticos e aquilo que representam, mas também das relações que unem a palavra ao pensamento.

\section{2 "O Cavalo que bebia cerveja": estranhamento, busca da identidade e linguagem}

O conto "O Cavalo que bebia cerveja", inicia-se com um narrador em primeira pessoa relatando a presença de um estrangeiro, palavra originária do latim extraneus (o que é de fora), aliás, a mesma que originou a palavra estranho:

Essa chácara do homem ficava meio ocultada, escurecida pelas árvores, que nunca se viu plantar tamanhas tantas em roda de uma casa. Era homem estrangeiro. De minha mãe ouvi como, no ano da espanhola, ele chegou, acautelado e espantado, para adquirir aquele lugar de todo defendimento; e a morada, donde de qualquer janela alcançasse de vigiar a distância, mãos na espingarda; nesse tempo, não sendo ainda tão gordo, de fazer nojo. Falavam que comia a quanta imundície: caramujo, até rã, com as braçadas de alfaces, embebidas num balde de água. Ver, que almoçava e jantava, da parte de fora, sentado na soleira da porta, o balde entre suas grossas pernas, no chão, mais as alfaces; tirante que, a carne, essa, legítima de vaca, cozinhada. Demais gastasse era com cerveja, que não bebia à vista da gente. Eu passava por lá, ele me pedia: - "Irivalíni, bisonha outra garrafa, é para o cavalo..." Não gosto de perguntar, não achava graça. Às vezes eu não trazia, às vezes trazia, e ele me indenizava o dinheiro, me gratificando. Tudo nele me dava raiva. Não aprendia a referir meu nome direito. Desfeita ou ofensa, não sou o de perdoar - a nenhum de nenhuma.(ROSA, 2001, p. 141-142)

O estranho estrangeiro é apresentado como tal em vários aspectos. Já nesse primeiro parágrafo, diz o narrador que ele morava em uma casa oculta por árvores; que chegou ao lugar "acautelado e espantado"; que tinha uma aparência repulsiva, era "gordo de fazer nojo"; alimentava-se de forma não convencional: que comia caramujo e rã, e não "carne legítima de 
vaca"; que comia fora de casa, na soleira da porta, de forma que se configura como um estrangeiro na própria casa; que comprava cerveja dizendo que era para o cavalo; e, por último, que chamava o narrador, Reivalino Belarmino, por Irivalíni, por desfeita ou ofensa, imperdoável, segundo este. Conformam-se aqui diversos níveis de estranhamento: cultural, comportamental, físico, mas o que marca mais, por ser imperdoável, segundo o narrador, é o estranhamento linguístico.

O aspecto físico do forasteiro é repulsivo, "cogotudo", ou seja, de nuca pronunciada, corcunda:

Minha mãe e eu sendo das poucas pessoas que atravessávamos por diante da porteira, para pegar a pinguela do riacho. - "Dei'stá, coitado, penou na guerra..." - minha mãe explicando. Ele se rodeava de diversos cachorros, graúdos, para vigiarem a chácara. De um, mesmo não gostasse, a gente via, o bicho em sustos, antipático - o menos bem tratado; e que fazia, ainda assim, por não se arredar de ao pé dele, estava, a toda a hora, de desprezo, chamando o endiabrado do cão: por nome "Mussulino". Eu remoia o rancor: de que, um homem desses, cogotudo, panturro, rouco de catarros, estrangeiro às náuseas - se era justo que possuísse o dinheiro e estado, vindo comprar terra cristã, sem honrar a pobreza dos outros, e encomendando dúzias de cerveja, para pronunciar a feia fala. Cerveja? Pelo fato, tivesse seus cavalos, os quatro ou três, sempre descansados, neles não amontava, nem aguentasse montar. Nem caminhar, quase, não conseguia. Cabrão! Parava pitando, uns charutos pequenos, catinguentos, muito mascados e babados. Merecia um bom corrigimento. Sujeito sistemático, com sua casa fechada, pensasse que todo 0 mundo era ladrão. (ROSA, 2001, p. 142)

É associado ao anti-Cristo, chamado de cabrão, vinculando aos estigmas que os cristãos medievais atribuíam aos judeus. Isso talvez explique a desconfiança que mostra em relação aos outros "com sua casa sempre fechada". Enfim, "estrangeiro às náuseas". Impressiona o narrador a casa trancada onde raramente o homem, seo Giovânio, entrava. $O$ estranhamento maior, centra-se, contudo, mais uma vez, na barreira linguística que separa o narrador do estrangeiro, este italiano, com sua "língua de bater ovos".

À medida que o tempo passa, a barreira diminui: o narrador, ajudado pelo estrangeiro nas ocasiões da doença e da morte de sua mãe, vai trabalhar para ele, como vigia da propriedade. A partir daí, surgem outros estrangeiros, dois homens sonsos vindos da capital, "os de fora", que têm como objetivo investigar seo Giovânio. Renova-se, aqui, a ideia do estranho. Reivalino passa a ser, ele mesmo, um estrangeiro para si mesmo e para os outros: 
diz ao delegado e aos investigadores que vai vigiar o patrão, mas não faz isso num primeiro momento; tem acesso, embora parcial, ao interior da casa do italiano, num segundo momento; torna-se, por fim, espião a serviço do delegado indo contar tudo o que sabe à polícia, agora por vingança.

O jogo de ocultações e revelações amplia-se: quando chegam os investigadores, seu Giovânio revela um segredo: o do cavalo que bebe cerveja. Num segundo momento, outro segredo: o do cavalo branco empalhado. O segredo final seo Giovânio só revela espontaneamente ao narrador: o corpo do irmão morto, desfigurado pela guerra. A morte e a consequente perda da identidade, metaforizada na falta de rosto do irmão Josepe, constituem uma espécie de revelação final de todo ser.

É nas palavras de seo Giovânio que encontramos uma chave interpretativa do conto: "Irivalíni...que esta vida....bisonha. Caspité?". O adjetivo bisonho, que em português significa inábil, sem experiência, tem origem no italiano, cujo significado original é necessidade de obter algo que falta. Essa dupla significação da palavra define a personalidade do narrador: de um lado sua inabilidade para descobrir o segredo, que só é revelado quando seo Giovânio deseja; de outro, a eterna necessidade de descobrir as coisas, sentimento que permeia a existência humana.

A necessidade da busca de identidade do narrador emblematiza-se na pronúncia incorreta do nome dele, falha que considera grave no italiano. Uma vez que não cita em nenhum momento a existência de um pai, descobre - e descobrimos com ele - que o pai é o estrangeiro seo Giovânio, que pagara as despesas fúnebres da mãe do narrador e que deixa como herança a ele o Mussolino (cachorro desprezado, mas que não saía de perto do italiano, assim como o próprio Reivalino); o cavalo que bebia cerveja (e o hábito de beber cerveja que o narrador não tinha antes); bem como a propriedade, a qual antes de vender ele manda desmatar, "cortar abaixo as árvores", metáfora do desvendamento do segredo existencial. No final, a revelação se processa justamente no plano linguístico: "capisquei", diz o narrador, utilizando o neologismo formado a partir do verbo italiano capire, que significa entender, compreender.

\section{2 "Sorôco, sua mãe e sua filha": estranhamento, razão, loucura e a passagem do prosaico ao poético}


Revista InterteXto / ISSN: 1981-0601

v. 6 , n. 2 (2013)

Em "Sorôco, sua mãe e sua filha", aparece de forma central o tema da loucura, aliado aos temas da partida, como metáfora da morte; da solidão; da esterilidade; da solidariedade. Sorôco, viúvo, descrito como "um homenzão, brutalhudo de corpo, com a cara grande, uma barba, fiosa, encardida em amarelo, e uns pés, com alpercatas: as crianças tomavam medo dele; mais, da voz, que era quase pouca, grossa, que em seguida se afinava", vinha à estação trazer a mãe e a filha loucas, únicas parentas que tinha, para serem levadas ao hospício em Barbacena:

O Agente da estação apareceu, fardado de amarelo, com o livro de capa preta e as bandeirinhas verde e vermelha debaixo do braço. - "Vai ver se botaram água fresca no carro... " - ele mandou. Depois, o guarda-freios andou mexendo nas mangueiras de engate. Alguém deu aviso: "Eles vêm!..." Apontavam, da Rua de Baixo, onde morava Sorôco. Ele era um homenzão, brutalhudo de corpo, com a cara grande, uma barba, fiosa, encardida em amarelo, e uns pés, com alpercatas: as crianças tomavam medo dele; mais, da voz, que era quase pouca, grossa, que em seguida se afinava. Vinham vindo, com o trazer de comitiva.

Aí, paravam. A filha - a moça - tinha pegado a cantar, levantando os braços, a cantiga não vigorava certa, nem no tom nem no se-dizer das palavras - o nenhum. A moça punha os olhos no alto, que nem os santos e os espantados, vinha enfeitada de disparates, num aspecto de admiração. Assim com panos e papéis, de diversas cores, uma carapuça em cima dos espalhados cabelos, e enfunada em tantas roupas ainda de mais misturas, tiras e faixas, dependuradas - virundangas: matéria de maluco. A velha só estava de preto, com um fichu preto, ela batia com a cabeça, nos docementes. Sem tanto que diferentes, elas se assemelhavam.

Sorôco estava dando o braço a elas, uma de cada lado. Em mentira, parecia entrada em igreja, num casório. Era uma tristeza. Parecia enterro. Todos ficavam de parte, a chusma de gente não querendo afirmar as vistas, por causa daqueles transmodos e despropósitos, de fazer risos, e por conta de Sorôco - para não parecer pouco caso. Ele hoje estava calçado de botinas, e de paletó, com chapéu grande, botara sua roupa melhor, os maltrapos. E estava reportado e atalhado, humildoso. Todos diziam a ele seus respeitos, de dó. Ele respondia: - "Deus vos pague essa despesa... "

O que os outros se diziam: que Sorôco tinha tido muita paciência. Sendo que não ia sentir falta dessas transtornadas pobrezinhas, era até um alívio. Isso não tinha cura, elas não iam voltar, nunca mais. De antes, Sorôco agüentara de repassar tantas desgraças, de morar com as duas, pelejava. Dai, com os anos, elas pioraram, ele não dava mais conta, teve de chamar ajuda, que foi preciso. Tiveram que olhar em socorro dele, determinar de dar as providências de mercê. Quem pagava tudo era o Governo, que tinha mandado o carro. Por forma que, por força disso, agora iam remir com as duas, em hospícios. O se seguir. (ROSA, 2001, p. 62-64) 
O narrador em primeira pessoa, que se coloca estrategicamente no ajuntamento de pessoas que estavam na estação para ver a cena da partida, conta-nos a história e mostranos a transformação de Sorôco de homem que inspirava medo a homem querido de todos, categoria que atingiu pelo sofrimento e tristeza que demonstra pela partida das duas mulheres: "De repente, todos gostavam demais de Sorôco".

O nome do protagonista sintetiza, tanto pelos possíveis significados quanto pelas possibilidades sonoras, um dos elementos-chave para a interpretação do conto: Sorôco nos remete a sou louco ou a senhor oco. Pode ainda remeter à palavra sóror, que significa, na origem, além de irmã, parente de sangue. Neste caso, associar Sorôco à figura feminina pode parecer, inicialmente, pouco apropriado para o contexto, pois o protagonista é caracterizado, no início do conto, com uma dureza muito masculina por meio da barba "fiosa" e quadrada e do jeito "brutalhão", mas, ao longo da narrativa, podemos verificar que esse significado também se aplica, isso porque Sorôco herda, como parente de sangue, por meio da cantiga que entoa, a loucura da mãe e da filha e também herda a ternura que faz com que as pessoas o vejam de modo diferente.

Quando as mulheres vão embora, o narrador nos diz que o protagonista ficou "no oco das beiras, sem queixa, exemploso". Essa tristeza ameniza os traços excessivamente duros e masculinos de Sorôco, acentuados pelo narrador no início do conto. O parentesco consanguíneo com as duas loucas fazem dele sóror enquanto a canção o torna fraterno.

Sorôco lamenta a face feminina perdida pela separação por meio da cantiga "de desatino, canto sem razão", dado lírico porque não diz, sugere. A cantiga será justamente o fator que impedirá que Sorôco se perca no oco, no vazio, deixado pela partida das duas parentas: "parecia que ia perder o de si, parar de ser".

Esse canto solidário, humanizador, que se contrapõe às razões práticas da existência, ter de mandar as duas para o hospício por não poder cuidar delas, contagia a multidão e reintegra o personagem à comunidade, justificando a locução pronominal "a gente", que o narrador em primeira pessoa utiliza para mostrar sua própria integração à ação: "A gente estava levando agora o Sorôco para a casa dele, de verdade. A gente, com ele, ia até aonde que ia aquela cantiga". Esse recurso linguístico irmana a cidade, as mulheres, Sorôco, o narrador, a multidão e, em última instância, o leitor, justamente por meio do estranhamento 
que a cantiga de desatino provoca nas pessoas. O uso do advérbio "aonde", no fecho do conto, intensifica as ideias de movimento, de continuidade, relacionado ao fluxo da existência, aos temas da viagem, da transformação, da morte. Diferente do advérbio "onde", que exprime situações locativas estáticas, "aonde" significa "ao lugar que (em que direção); para o lugar que (para que direção); para qual lugar", sugerindo a ideia de movimento.

Também o fluxo da existência aparece no carro que transportou as mulheres, que "lembrava um canoão no seco, navio", cujas janelas eram "enxequetadas", ou seja, enxadrezadas de grades. $O$ trem sugere as imagens antitéticas de liberdade e prisão: tratase de uma viagem que emblemática que apresenta de um lado a liberdade; de outro, a morte: duas faces da mesma moeda.

Daí uma espécie de revelação, de Sorôco, dos habitantes da cidade, do narrador e do leitor que, sintomaticamente, ocorrerá ao ar livre, na hora de muito sol, próximo ao meio-dia. Esses elementos espaciais e temporais associam-se à abertura, à razão, e conduzem à revelação a qual, paradoxalmente, ocorre por meio do canto desatinado, da loucura. Este jogo de elementos paradoxais assim dispostos nos remete ao próprio paradoxo da existência: vida / morte, razão / loucura codificados literariamente pela passagem do prosaico (narrativo) ao poético (canto).

Assim Sorôco, entre a mãe, toda vestida de negro, e a filha, toda vestida de panos coloridos, torna-se o vértice de um triângulo: síntese da existência humana, porque todos a ele se irmanam. Essa união só se processa por meio da herança deixada pelas mulheres que se materializa na cantiga, a loucura, emblema do estranhamento.

\section{3 "A Terceira margem do rio": estranhamento, transcendência e desreificação}

Em "A Terceira margem do rio", encontramos, sob diversas formas, o estranhamento:

Nosso pai era homem cumpridor, ordeiro, positivo; e sido assim desde mocinho e menino, pelo que testemunharam as diversas sensatas pessoas, quando indaguei a informação. Do que eu mesmo me alembro, ele não figurava mais estúrdio nem mais triste do que os outros, conhecidos nossos. Só quieto. Nossa mãe era quem regia, e que ralhava no diário com a gente - minha irmã, meu irmão e eu. Mas se deu que, certo dia, nosso pai mandou fazer para si uma canoa. 
Revista InterteXto / ISSN: 1981-0601

v. 6 , n. 2 (2013)

Era a sério. Encomendou a canoa especial, de pau de vinhático, pequena, mal com a tabuinha da popa, como para caber justo o remador. Mas teve de ser toda fabricada, escolhida forte e arqueada em rijo, própria para dever durar na água por uns vinte ou trinta anos. Nossa mãe jurou muito contra a idéia. Seria que, ele, que nessas artes não vadiava, se ia propor agora para pescarias e caçadas? Nosso pai nada não dizia. Nossa casa, no tempo, ainda era mais próxima do rio, obra de nem quarto de légua: o rio por aí se estendendo grande, fundo, calado que sempre. Largo, de não se poder ver a forma da outra beira. $E$ esquecer não posso, do dia em que a canoa ficou pronta.

Sem alegria nem cuidado, nosso pai encalcou o chapéu e decidiu um adeus para a gente. Nem falou outras palavras, não pegou matula e trouxa, não fez a alguma recomendação. Nossa mãe, a gente achou que ela ia esbravejar, mas persistiu somente alva de pálida, mascou o beiço e bramou: - "Cê vai, ocê fique, você nunca volte!" Nosso pai suspendeu a resposta. Espiou manso para mim, me acenando de vir também, por uns passos. Temi a ira de nossa mãe, mas obedeci, de vez de jeito. O rumo daquilo me animava, chega que um propósito perguntei: - "Pai, o senhor me leva junto, nessa sua canoa?" Ele só retornou o olhar em mim, e me botou a bênção, com gesto me mandando para trás. Fiz que vim, mas ainda virei, na grota do mato, para saber. Nosso pai entrou na canoa e desamarrou, pelo remar. E a canoa saiu se indo - a sombra dela por igual, feito um jacaré, comprida longa. (ROSA, 2001, p. 79-80)

O pai era "homem cumpridor, ordeiro, positivo". De repente, ele manda construir uma canoa, despede-se da família e lança-se no rio, em uma espécie de navegação eterna. O discurso sintético de despedida da matriarca, que regia efetivamente o lar, "Cê vai, ocê fique, você nunca volte!', acentua, por meio uso do pronome de tratamento cada vez mais formal, o distanciamento que se impõe a partir do acontecido.

O fato de o homem "executar a invenção de se permanecer naqueles espaços do rio" sem nunca saltar à terra é a estranheza de uma verdade que estarrece "de todo a gente", conforme as palavras do narrador. Temos aqui, novamente, a ideia do estranhamento ligado à consciência de algo que reside nas pessoas, mas que não conseguem ver, a não ser quando alguém se lança ao insólito e lhes revela. É essa a função do pai, que faz, concretamente, no rio, o que todos fazemos, na terra: existir ao sabor do fluxo temporal:

[...].Nossa mãe muito não se demonstrava.

Mandou vir o tio nosso, irmão dela, para auxiliar na fazenda e nos negócios. Mandou vir o mestre, para nós, os meninos. Incumbiu ao padre que um dia se revestisse, em praia de margem, para esconjurar e clamar a nosso pai o 'dever de desistir da tristonha teima. De outra, por arranjo dela, para medo, vieram os dois soldados. Tudo o que não valeu de nada. Nosso pai passava ao largo, avistado ou diluso, cruzando na canoa, sem deixar ninguém 
se chegar à pega ou à fala. Mesmo quando foi, não faz muito, dos homens do jornal, que trouxeram a lancha e tencionavam tirar retrato dele, não venceram: nosso pai se desaparecia para a outra banda, aproava a canoa no brejão, de léguas, que há, por entre juncos e mato, e só ele conhecesse, a palmos, a escuridão daquele.

A gente teve de se acostumar com aquilo. Às penas, que, com aquilo, a gente mesmo nunca se acostumou, em si, na verdade. Tiro por mim, que, no que queria, e no que não queria, só com nosso pai me achava: assunto que jogava para trás meus pensamentos. O severo que era, de não se entender, de maneira nenhuma, como ele aguentava. De dia e de noite, com sol ou aguaceiros, calor, sereno, e nas friagens terríveis de meio-do-ano, sem arrumo, só com o chapéu velho na cabeça, por todas as semanas, e meses, e os anos - sem fazer conta do se-ir do viver. Não pojava em nenhuma das duas beiras, nem nas ilhas e croas do rio, não pisou mais em chão nem capim. Por certo, ao menos, que, para dormir seu tanto, ele fizesse amarração da canoa, em alguma ponta-de-ilha, no esconso. Mas não armava um foguinho em praia, nem dispunha de sua luz feita, nunca mais riscou um fósforo. O que consumia de comer, era só um quase; mesmo do que a gente depositava, no entre as raízes da gameleira, ou na lapinha de pedra do barranco, ele recolhia pouco, nem o bastável. Não adoecia? E a constante força dos braços, para ter tento na canoa, resistido, mesmo na demasia das enchentes, no subimento, aí quando no lanço da correnteza enorme do rio tudo rola o perigoso, aqueles corpos de bichos mortos e paus-de-árvore descendo - de espanto de esbarro. E nunca falou mais palavra, com pessoa alguma. Nós, também, não falávamos mais nele. Só se pensava. Não, de nosso pai não se podia ter esquecimento; e, se, por um pouco, a gente fazia que esquecia, era só para se despertar de novo, de repente, com a memória, no passo de outros sobressaltos. (ROSA, 2001, p. 8182)

A imagem do rio associa-se ao fluxo da existência; à passagem e, consequentemente, à efemeridade da vida; à viagem em seus diversos modos, tanto do ponto de vista físico quanto metafísico. O meio líquido, volátil, emblematiza, pela profundeza, o inconsciente, o mistério. O rio, personificado no conto, é a imagem o pai, homem sério e calado: "o rio se estendendo por aí grande, fundo, calado que sempre. Largo, de não se poder ver a forma da outra beira". No final, é o narrador - o filho - que não consegue substituir o pai, que se funde ao rio, pedindo que o coloquem em uma canoa depois de sua morte e a depositem no rio: "nessa água que não para, de longas beiras: e, eu, rio abaixo, rio a fora, rio a dentro - o rio". Dessa forma, a canoa-esquife torna-se o meio de transporte para a transcendência, sugerida pela terceira margem, que nos remete novamente à imagem triângulo. Essa terceira margem, sendo algo inexistente no mundo concreto, simboliza a busca metafísica do ser, entre os limites das duas margens palpáveis: a vida (a que estamos) e a morte (a outra beira que não se vê). 
O conto ainda nos apresenta uma importante reflexão sobre a sociedade e a forma como ela lida com o estranhamento. A comunidade não compreende o home estranho que navega indefinidamente. Especula-se, imediatamente, como justificativa para a atitude do homem, loucura ou doença grave, estigmas sociais que tentam tornar o pai um ser de exceção e, portanto, têm a função preservar o resto do mundo no plano da ordem. A sociedade nega aquilo que teme e que poderia desintegrá-la pelo contágio, por isso todos tentam trazer o homem de volta, reintegrá-lo às estruturas fixas representadas pela terra firme.

Desse modo, as formas de convencimento que se aplicam ao pai são todas ligadas, simbolicamente, às formas autoritárias e práticas de organização e percepção das estruturas sociais que condicionam o indivíduo: a igreja, a polícia e a imprensa. A mãe chama o padre, para que fosse à margem "para esconjurar e clamar a nosso pai o dever de desistir da tristonha teima"; depois, chama a polícia para intimidar o homem: "vieram dois soldados"; e, por fim, aparecem os homens do jornal, instituição que simboliza o vínculo direto com a realidade cotidiana: "[os homens do jornal] trouxeram a lancha e tencionavam tirar retrato dele". Estes nada conseguiram, pois o pai desaparecia entre os juncos e mato, ambiente de escuridão, só conhecido por ele. Sendo assim, todas as tentativas de reinserção do pai no meio social são frustradas pelo firme propósito do navegante em buscar a terceira margem.

À medida que o tempo passa, o pai vai se identificando cada vez mais com a natureza, num processo de desreificação: não necessitava de roupas; não desembarcava, portanto não punha o pé em solo firme; dormia só o necessário com a canoa amarrada; comia o mínimo, "só o quase; não armava um foguinho; nunca falou mais palavra". A roupa, o fogo e a palavra são objetos culturais que marcaram a passagem humana da natureza para a cultura, caminho que o protagonista realiza de forma inversa, num processo de reintegração que nos remete à proposta das "Correspondências" de Baudellaire. O homem integra-se à natureza a tal ponto que resiste às enchentes e à correnteza enorme do rio: "aos bichos mortos e paus-de-árvore descendo - de espanto de esbarro".

O filho, narrador em primeira pessoa, que o tempo todo se identifica tanto física quanto psicologicamente com o pai, é único que fica nas terras: "Minha irmã se mudou, com o marido, para longe daqui. Meu irmão resolveu e se foi, para uma cidade. Os tempos mudavam, no devagar depressa dos tempos. Nossa mãe terminou indo também, de uma 
vez, residir com minha irmã, ela estava envelhecida". A cidade, que representa o progresso, arrasta todos para longe do rio. Responsável pela escassa alimentação do pai, ao narrador cabe a tarefa de dar continuidade ao processo de reintegração à natureza iniciado pelo pai, mas não consegue. Esse "falimento", essa frustração, traduz-se por meio da impotência linguística: "Sou homem depois desse falimento? Sou o que não foi, o que vai ficar calado". O tempo em que vive o narrador é o tempo profano em que está longe da natureza e do tempo sagrado do pretérito representado pelo fluxo do rio e agora distante: "Nossa casa, no tempo, ainda era mais próxima do rio".

\section{Considerações finais}

As três "estórias" roseanas, cuja feição mítica contrasta com o logos do discurso histórico, têm como ponto comum a oralidade que se constrói sob o manto de uma enunciação aparentemente simples, cujo objetivo é mobilizar estruturas complexas numa espécie de trabalho de desfossilização da linguagem prosaica. Para tanto, o narrador apropria-se de ferramentas estilísticas que unem a expressão ao pensamento, serve-se de neologismos, sonoridade, construções sintáticas e um léxico repleto de sugestões simbólicas, entre outros recursos, que desprendem as palavras das amarras tradicionais que as vinculam a objetos específicos do cotidiano e potencializam o poder evocador da expressão. Nesse sentido, temos aquele aspecto durativo, próprio do discurso literário, que prolonga a percepção, bem como desperta no leitor o aspecto humanizador da literatura.

Assim, num jogo de estranhamento e revelação, sempre pautado pelo potencial expressivo da construção da linguagem poética, os três contos tratam de temas que são universais: a busca da identidade, a dicotomia razão/loucura, a busca transcedental das origens e do destino humanos. Ambientados no interior do Brasil, contudo, não é a cor local nem são os cenários pitorescos que se sobressaem. O homem não é mero produto do meio, também não se contrapõe ao meio, mas é o próprio meio. A natureza, e o homem como parte dela, transfiguram-se metafisicamente a caminho da transcendência, cujo transporte mais adequado é o do discurso poético que relativiza o logos e reapresenta o mito, não apenas como ficção, mas como verdade primordial. 


\section{Referências}

BOSI, Alfredo. O Conto brasileiro contemporâneo. São Paulo: Cultrix, 1978.

BALLY, Charles. Traité de stylistique française. Paris: Klincksieck, s/d.

CANDIDO, Antonio. Tese e antítese. São Paulo: TA Queiroz, 2000.

. O direito à literatura. In: Vários escritos. São Paulo: Duas Cidades,

1995.

EAGLETON, Terry. Teoria da literatura - uma introdução. São Paulo: Martins Fontes, 2003.

CHKLOVSKI, V. A Arte como processo. In: TODOROV, Tzvetan. Teoria da literatura - I Textos dos formalistas russos apresentados por Tzevetan Todorov. Lisboa: Edições 79, 1999.

MARTINS, NILCE Sant'Anna. O Léxico de Guimarães Rosa. São Paulo: Edusp, 2001.

ROSA, Guimarães. Primeiras Estórias. Rio de Janeiro: Nova Fronteira, 2001.

Dicionário eletrônico Houaiss da Língua Portuguesa - http://houaiss.uol.com.br 